\title{
ヒトの随伴性学習における潜在制止の実験的検討
}

\author{
一付加刺激の役割に着目して一 \\ ○沼田恵太郎 ${ }^{1}$ ・ 嶋崎恒雄 ${ }^{2}$ \\ ( ${ }^{1}$ 関西学院大学大学院文学研究科 $\cdot{ }^{2}$ 関西学院大学文学部)
}

キーワード: ヒトの随伴性学習・潜在制止・抑制率と評定値

\begin{abstract}
Latent inhibition in human contingency learning: Focusing on the role of filler cues
Keitaro NUMATA ${ }^{1}$ and Tsuneo SHIMAZAKI ${ }^{2}$
\end{abstract}

('Graduate School of Humanities, Kwansei Gakuin University., ${ }^{2}$ School of Humanities, Kwansei Gakuin University)

Key words: human contingency learning, latent inhibition, suppression ratio and rating

古典的条件づけ事態では、あらかじめ条件刺激だけを経験 しておくと、その後で条件刺激を無条件刺激と対提示した場 合に、条件づけの獲得が遅れることが知られている。この現 象は潜在制止と呼ばれ、生活体がいかに情報の取捨選択を行 うか」という疑問を解決するために、現在に至るまで盛んに 検討されてきた。しかし、これらの研究の多くは動物を対象 としたものであり、一方でヒトを対象とした例証は必ずしも 多くない (e.g., Nelson \& Sanjuan, 2006; 沼田・嶋崎, 2009)。

たとえば、沼田・嶋崎（2009）は動物の古典的条件づけで 一般的に用いられる抑制率 (e.g., Annau \& Kamin, 1961) を ヒトに応用した実験を行い、潜在制止の確認に成功している。 しかし、この実験では統制群において条件づけ 1 試行目から 大きな抑制がみられており、この抑制を減弱する必要がある。

本研究の目的は、ヒトの随伴性学習事態において潜在制止 がみられるか否かを再検討することであった。具体的には、 条件づけ期とは異なる手がかり（条件刺激と対応）が先行提 示される B exposed 群と、同じ手がかりが先行提示されるA exposed 群の 2 群を設定し、結果（無条件刺激と対応）の条 件づけが A exposed 群において遅滞するか否かを検討した。 従属变数は行動指標（抑制率）と随伴性判断（評定值）の 2 種類であった。なお、本研究では沼田・嶋崎（2009）の実験 デザインを改変し、新たに付加刺激（i.e., $F_{1}, F_{2}$ ) を用いた。 これは先行提示期と条件づけ期において、手がかりと結果の 変化を経験させるために実施された。

\section{方 法}

実験参加者 大学生 24 名（男性 12 名、女性 12 名）。平均年 齢は 20.7 歳 (18 歳から 24 歳)。攻撃ボタン押しの訓練成績 が等しくなるように、実験参加者は上述の 2 群に分割された。 実験課題 実験課題はコンピュータを用いたビデオゲームの 形態であり、ゲームでは一定時間ごとにインベーダーが出現 を繰り返した（Figure 1)。実験参加者はディスプレイ上に出 現するインベーダーを撃退し、できるだけ多くの得点を獲得 するよう求められた。実験参加者は攻撃ボタンを押すことに よって、インベーダーを撃退するレイザーガンを発射するこ とができた。もしも、インベーダー表示時にレイザーガンが 発射されたならば、インベーダーが爆発し得点カウンタに 1 点が加算された（FI0.3 秒 LHO.2 秒）。また、ゲームでは実験 参加者はインベーダーによって攻撃を受けた (結果)。実験参 加者はインベーダーの攻撃を予測するセンサーの点灯を手が かりに、5 回以上防御ボタンを押寸ことによってバリアーを 展開することができた（閒隔 DRH）。もしも、バリアーを展 開しなかった場合はダメージを受け、得点カウンタから 30 点が減算された。センサーの点灯は 5 秒であり、ITI は平均で 20 秒（15 秒から 25 秒）であった。なお、実験課題ではセン サーが点灯した 5 秒間 $(\mathrm{X})$ とその直前の 5 秒間 $(\mathrm{Y})$ の攻撃 ボタン押し行動の回数が測定され、それらに基づいて抑制率 が算出された $[\mathrm{X} /(\mathrm{X}+\mathrm{Y})]$ 。
実験手続き 教示と攻撃ボタン押しの訓練を行った後、実験

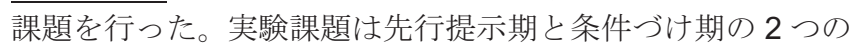
フェイズから構成された（Table 1)。先行提示期ではB ある いはA が 0\%の確率で結果と対提示され、F 1 が 100\%の確率 で結果と対提示された（各 10 試行）。条件づけ期では A が 100\%の確率で結果と対提示され、 $F_{2}$ が $0 \%$ の確率で結果と 対提示された（各 10 試行）。センサーの点灯色は赤・緑・青・ 黄の 4 種類であり、各手がかりのセンサーの点灯色への割り 当ては実験参加者間で平衡された。また、条件づけ期の直後 には評定期が挿入され、実験参加者は A が結果を予測するか 否かについて評定を求められた。評定は０（全く予測しない） から 100 （完全に予測する）までの尺度上に縦線を引くこと によって行われた。

\section{結果および考察}

Figure 2 の左パネルには条件づけ期における A 提示中の 平均抑制率が、右パネルには平均評定值がそれぞれ示されて いる。左パネルから明らかなように、B exposed 群では 2 試 行目から攻撃ボタン押しの抑制がみられ、A exposed 群では 5 試行目から大きな抑制がみられた。これは A exposed 群に おいて条件づけの獲得が遅滞したことを示している。また、 条件づけ期 10 試行目では各群で同程度の抑制がみられたが (左パネル)、その直後に測定された評定值はA exposed 群に おいて低かった（右パネル）。これは課題の最後に測定された 評定值が、リアルタイムで測定された抑制率よりも広範囲の 頻度情報を反映したことを示している。

以上の結果から、抑制率と評定值において潜在制止がみら れたこと、および抑制率と評定值が異なる範囲の頻度情報を 反映したことが示された。また、B exposed 群では付加刺激 の使用により、条件づけ期 1 試行目の抑制が減弱したことが 示唆された。これは先行研究にない新しい知見であった。
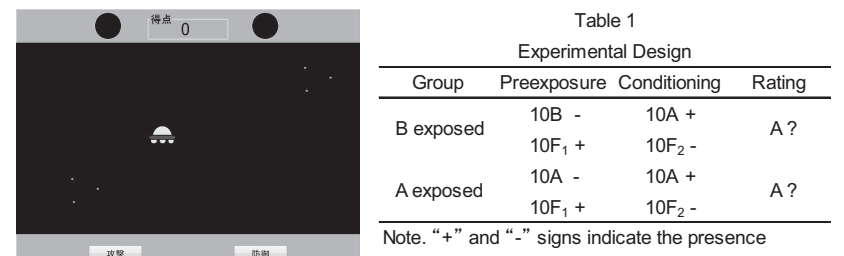

Figure 1. Experimental Task.
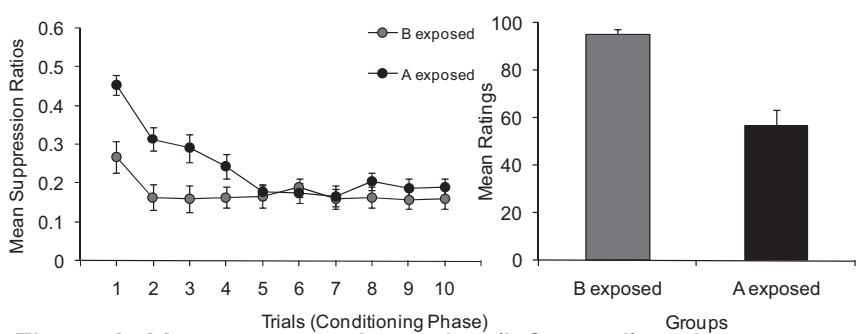

Figure 2. Mean suppression ratios (left panel) and mean ratings (right panel). Error bars show the SEM. 